Acta Theriologica 45 (4): 537-547, 2000.

PL ISSN 0001-7051

\title{
Diet composition of wolves Canis lupus in east-central Finland
}

\author{
Inge GADE-JØRGENSEN and Rie STAGEGAARD*
}

\begin{abstract}
Gade-Jørgensen I. and Stagegaard R. 2000. Diet composition of wolves Canis lupus in east-central Finland. Acta Theriologica 45: 537-547.

In east-central Finland, wolf Canis lupus Linnaeus, 1758 scats were collected from January to November 1997. The summer (May-September) and winter (October-April) diet were determined from 370 scats using four scat-analysis methods: frequency of occurrence, measured dry weight, relative volume and the linear regression model of Weaver (1993). An overall agreement of diet assessment was found between the methods. Moose Alces alces was far the most important prey species in both seasons, accounting for $88 \%$ (summer) and $96 \%$ (winter) of consumed mammal biomass. Other food types were: hare, beaver, badger, dog, pig, cattle, birds, small rodents, berries, insects, and fishes. The presence of domestic pig and cattle remains implied scavenging behaviour by the wolves. The inclusion of dogs leads to conflict between man and wolves. From 260 scats the summer diet of two wolf packs and the winter diet of one of the packs were determined. No notable seasonal difference in diet was found. An inter-pack difference in summer diet was found, resulting from a relatively lower exploitation of moose (69\% versus $93 \%$ of consumed mammal biomass) and a corresponding wider use of secondary food types, especially hare, by one of the packs.

Finnish Game and Fisheries Research Institute, Ohtaojantie 19, 93400 Taivalkoski, Finland

Key words: Canis lupus, wolf diet, consumption of moose, Finland
\end{abstract}

\section{Introduction}

The wolf Canis lupus Linnaeus, 1758 population in Finland was estimated to total 100-140 individuals in 1997 (I. Kojola, pers. comm.). The majority of the wolves live in east-central Finland, which is the only area in the country where wolf reproduction is known to occur (Ministry of Agriculture and Forestry 1996). The eastern Finnish wolf population can be viewed as the western edge-population of the continuous and larger Russian wolf range. The core area of the approximately 40-50 Scandinavian wolves is located in south-central Sweden (Olsson et al. 1997) and probably little migration of wolves occurs between Finland and the Scandinavian Peninsula, although a few cases of wolves crossing the border are reported (Pulliainen 1982). The ecology of the Finnish wolf population is poorly investigated

* Corresponding author: The Big Four of Scandinavia, Nygard 7, 68050 Ekshärad, Sweden, e-mail: rie@bigfour-scandinavia.com 
and only a few papers exist on the subject (Pullianen 1965, 1979, 1982, 1993, Nygrén 1980). A common, although undocumented claim is that wolf predation is heavily limiting the moose numbers in east-central Finland.

The aim of this study was to investigate wolf diet composition from scats in east-central Finland and particularly to evaluate the relative importance of moose in the diet. Moose is the only wild ungulate in the study area (Helle et al. 1997), and we hypothesized moose to be the major food source for the wolves in accordance with the findings of the majority of wolf diet studies, revealing that ungulates are the primary prey of wolves (eg Okarma 1995). As recommended by Ciucci et al. (1996) we used more than one scat-analysis method, since comparison of results and interpretation of possible discrepancies help to avoid misleading conclusion by relying on a single method.

\section{Study area}

Wolf feeding habits were studied in east-central Finland in the province of North Karelia. The total scat collection area was approx. $1300 \mathrm{~km}^{2}$ and was centred around $63^{\circ} \mathrm{N}, 31^{\circ} \mathrm{E}$. The area is relatively flat with gently rolling hills (140-250 m a.s.l.). Forest-land makes up $45 \%$, bogs $35 \%$, water $14 \%$ and human settlements, fields etc $6 \%$ of the total area in the district. Human density in the district is approx. 3.8 inhabitants $/ \mathrm{km}^{2}$ of dry land. Logging activity is extensive. Vegetation in the area is mainly coniferous forest dominated by Scots pine Pinus sylvestris and Norway spruce Picea abies which totals $78 \%$ and $15 \%$ of the forest land, respectively (Kalliola 1973).

The climate is characterized by warm summers and cold winters, with mean temperatures of $15.8^{\circ} \mathrm{C}$ in July and $-12.1^{\circ} \mathrm{C}$ in January. For the purpose of this study summer is defined as the 5 -months period (May-September) comprising the usual snow free months. The average midwinter snow cover is $<65 \mathrm{~cm}$, although in some years it exceeds 1 metre.

In the end of 1997 wolf density was estimated to 9 wolves $/ 1000 \mathrm{~km}^{2}$ (I. Kojola, pers. comm.). Other large predators inhabiting the area include brown bear Ursus arctos, wolverine Gulo gulo and lynx Lynx lynx. Medium-sized carnivores include fox Vulpes vulpes, badger Meles meles and raccoon dog Nyctereutes procyonoides. The moose density was estimated to be approx. $0.2 \mathrm{moose} / \mathrm{km}^{2}$ in 1997 (T. Nygrén, unpubl.). Other potential wolf prey species include beaver Castor canadensis, hare Lepus timidus, various tetraonides (capercaillie Tetrao urogallus, black grouse Tetrao tetrix, willow grouse Lagopus lagopus), and a variety of small rodent and bird species. Livestock on pastures is rare in the study area. Within the study area, three baiting sites were used by nature photographers during the year of study. During the autumn hunt, the use of hunting dogs is widespread, but otherwise free roaming dogs are rare.

\section{Material and methods}

\section{Scat collection}

Wolf scats were collected from January to November 1997. Local people and members of the Frontier Guard of Finland supported the study by collecting scats on occasion. In winter, the authors collected scats by following wolf tracks on snowmobiles and skies, and in summer along forest roads patrolled by car every 1-8 week. Scats deposited within $50 \mathrm{~m}$ of each other and of similar age were pooled to one observation to ensure an independent scat sample. To differentiate between wolf scats and other scats, the dimensions (Weaver and Fritts 1979), structure, deposit site (eg close to wolf travel routes or kill-sites) and nearby tracks were used. Deposit time of a scat was estimated using 
knowledge of wolf movements, time span since last sampling effort and scat appearance compared with exposure of deposition site. The scats were categorized as old ( $>2$ weeks) or fresh $(<2$ weeks). For feasible comparison between studies we used only collectable (sensu Floyd et al. 1978) and non-weathered (sensu Reynolds and Aebischer 1991) scats in the analysis.

During the year of study, reports on wolf activity (ie observations, tracks, howling, kill-sites) were collected and locations were revisited to verify the information when possible. These data plus data on wolf movements obtained by wolf tracking by the authors were compared (total 633 reports) with the aim of outlining wolf territories, so wolf scats could be assigned to individual packs. For two packs (hereafter referred to as Kurikka-pack and Möhkö-pack) parts of their respective territories were outlined and we felt confident when assigning scats inside the boundaries of these areas. Scats deposited outside these areas were excluded from analysis of pack diet. Tracking during winter indicated 7-8 individuals in the Kurikka-pack and 5 individuals in the Möhkö-pack.

A total of 416 scats were sampled. Fourteen $(3.4 \%)$ were classified as non-collectable, $5(1.2 \%)$ as weathered and 3 as bear scats, since ants (Formicidae) were the main content. Twenty-four $(6 \%)$ of the remaining 394 scats were pooled, leaving a total sample of 370 scats for dietary analysis. For the Kurikka-pack sample sizes were large enough to asses winter $(n=104)$ and summer $(n=112)$ diet. For the Möhkö-pack only summer diet could be assessed $(n=44)$.

\section{Laboratory procedure}

Laboratory procedures followed Reynolds and Aebischer (1991) and Ciucci et al. (1996). Scats were oven-dried at $90^{\circ} \mathrm{C}$ and weighed. The dried scat was immersed in a measuring cylinder with water and the total scat volume was determined. Scats were soaked in water with detergent before macro-components were separated from micro-components in a sieve (mesh size $0.5 \mathrm{~mm}$ ). We followed the general tendency of discarding the micro-components from analysis (Ciucci et al. 1996) assuming the micro- and macrocomponent fraction contained prey remains in the same proportions. Remains from different food types were separated for each scat. Consumed items with little or no nutritional benefit to the wolf (NFI), eg pine needles and rumen content, were pooled together. All remains were dried at $90^{\circ} \mathrm{C}$ and weighed. The density of each scat was calculated as total scat dry weight divided by total scat volume.

For each scat relative proportions by volume of remains were estimated by eye by placing the remains on a paper provided with a grid-pattern. All proportions were estimated to nearest $2.5 \%$ and the sum of all relative proportions per scat was set to $100 \%$. Firstly, all food types and NFI were assigned a proportion, and these proportions were used in calculation of the diet composition by the relative volume method. Secondly, NFI and food types with a proportion $\leq 2.5 \%$ (trace-amount) were ignored and the proportion of each remaining food type was estimated. These proportions were used to calculate whole scats units for the biomass model.

Guard hairs found in the scats were used to identify mammal prey. Macroscopic and microscopic characteristics were compared with reference hairs from the study area and reference manuals (eg Debrot et al. 1982, Teerink 1991). Technique for microscopic examination followed Teerink (1991). For identification, remains of fruit, insects and birds plus mammal bone, claw and tooth were compared with local reference material. Moose juveniles (up to 4-5 months) were identified by the reddish colour of their pelage present from birth around May to the first autumn molt in August/September, when they acquire a darker coat resembling adult pelage (Peterson 1955). Accuracy of identification of mammal hairs was assessed. A blind test was made on 50 different hairs from 22 different wild and domestic species present in the study area. Accuracy of moose age was $100 \%(n=8)$, and species identification $98 \%(n=50)$. The lower accuracy is due to one case where a wolf hair was mis-identified as a raccoon dog hair. This inaccuracy is assumed to be insignificant for the result of this study, because no hair was identified as raccoon dog.

\section{Scat-analysis methods}

Frequency of occurrence is expressed as the frequency with which each food type occurs as a percentage of the total number of occurrences of all food types. Measured dry weights of remains are 
expressed as the sum of weights of all remains for a particular food type. Relative volumes of remains are expressed as the sum of all volumes of remains for a particular food type. Biomass ingested was estimated from the linear regression model of Weaver (1993): $y=0.439+0.008 x\left(R^{2}=0.78\right)$, obtained by feeding trials of captive wolves, where $y$ represents the biomass ingested $(\mathrm{kg})$ per collectable scat produced and $x$ is the live weight $(\mathrm{kg})$ of the prey species recovered in the scat. The model is restricted to mammalian prey since only mammals were included in the feeding trials. Because some scats revealed more than one food type, the number of scats containing a given food type was calculated as the sum of all relative volumes expressing the number of whole scat units (Floyd et al. 1978). The live weight of prey used in the model has to account for differences in size of the prey population killed by wolves. An adjusted weight is particularly relevant for large prey like ungulates, which exhibit huge variation in body sizes depending on age and sex. In scat analysis it is possible to isolate scats containing juvenile ungulates $(<4-5$ months). To determine age structure for moose in the wolf diet after September, the proportions of calves and adults ( $>1$ year) in wolf-killed moose found in the study area during winters from 1987-1997 were assumed to represent the proportions eaten during winter 1997. Sixteen moose carcasses were investigated by the authors during the year of study and 21 carcasses were investigated by personnel at Ilomantsi Game Research Station during winters 1987-1996. We calculated an average winter moose weight based on the proportion of adults and calves found in the sample of wolf-killed moose. Sex ratio was assumed to be equal and the average moose killed by wolves were assumed to weigh the same as the average moose killed by hunters. Average carcass weight of hunter-killed adult cows and bulls were obtained from Nygrén and Pesonen (1989) and the average carcass weight of calves was obtained from Nygrén and Nygrén (1976) and T. Nygrén (unpubl.). Carcass weights were assumed to be $55 \%$ of the living weight (Blood et al. 1967). Live weights $(\mathrm{kg}$ ) of prey used in the model were: adult moose $340 \mathrm{~kg}$, calf moose in May-June, July-August and during winter $30 \mathrm{~kg}, 70 \mathrm{~kg}$ and $145 \mathrm{~kg}$, respectively, hare $2.8 \mathrm{~kg}$, beaver $12.5 \mathrm{~kg}$, pig $100 \mathrm{~kg}$, cattle $510 \mathrm{~kg}$, and $\operatorname{dog} 20 \mathrm{~kg}$. The biomass of small rodents was calculated as the number of occurrences multiplied with an assumed body weight of 25 grams as in Olsson et al. (1997). Data on wolf body weight were collected using 4 traffic-killed, 1 wolf-killed and 62 wolves shot by hunters in the district of North-Karelia, Finland during the months of October to March from 1979-1997. All data were collected from autopsy reports obtained through the Finnish Game and Fisheries Research Institute and archives of Game Management District of North Karelia.

To test if the difference in average density of old and fresh scats was significant a $t$-test (two-sample) was used (Sokal and Rohlf 1981: 226). Likewise, a $t$-test (two-sample) was used to test whether the difference between the average dry weight of macro-components of old and fresh scats was significant. To assess if scat-analysis methods differed in assessment of wolf diet composition, we simultaneously compared the relative importance of each food type achieved by different scat-analysis methods. We obtained the overall agreement by using Kendall coefficient of concordance, $W$ (Siegel 1956: 231). Significance of $W$ was tested following Siegel (1956: 235). In all statistical tests $p<0.05$ was necessary for significance. The confidence limits of the estimated relative importance of different food types in the diet were measured with the 95-percentiles of 5000 bootstrap estimates (Reynolds and Aebischer 1991).

\section{Results}

Fresh scats $(n=123)$ had an average density of $0.88 \mathrm{~g} / \mathrm{cm}^{3}$, which was significantly higher than the average density of old scats $(n=64)$ of $0.80 \mathrm{~g} / \mathrm{cm}^{3}$ $\left(F_{64,123}=1.32, \mathrm{~ns} ; t_{185}=1.76,0.025<p<0.05\right)$, whereas there was no statistical difference in the average fraction of macro-components by dry weight of old and fresh scats $\left(F_{64,123}=1.54, \mathrm{~ns} ; t_{185}=0.85, \mathrm{~ns}\right)$. Only one food type was present in $225(86.5 \%)$ of the scats. Two and three food types were found in $9.2 \%$ and $3.5 \%$ of the scats, respectively. In 2 scats no remains of food were present. Remains of 
Graminae were common in the scats from April to October occurring in 27\% of scats deposited in this period $(n=163)$. Most often the grass was present in well-ordered bundles, and in some cases $(n=5)$ it occupied more than $50 \%$ and up to $100 \%$ of the scat by relative volume which indicates that Graminae was ingested voluntarily by wolves. Wolf hairs were found in $6.2 \%$ of all scats and they always occurred in trace-amount, which suggests ingestion by grooming. A higher frequency of wolf-hair observed in scats deposited during summer (mainly June and July) was probably caused by nursing of pups.

Simultaneous comparison of rankings of food types by the four scat-analysis method showed significant concordance in all cases $(0.85<W<0.93, p<0.01)$. Because of the high concordance between the four scat-analysis methods in assessment of diet, only results from the frequency of occurrence method (the most adopted scat analysis method in carnivore diet studies) and the biomass method (the ecologically most relevant method) is shown and used in further discussion.

Moose was far the most important prey species recovered in the total winter scat sample, accounting for $86 \%$ of all occurrences and $96 \%$ of consumed mammal biomass (Table 1). In summer, moose also dominated as prey, but to a lesser extent accounting for $58 \%$ of all occurrences and $88 \%$ of consumed mammal biomass. Consequently the summer diet consisted of a larger proportion of secondary prey,

Table 1. Wolf diet in east-central Finland in 1997 as assessed by two scat-analysis methods and expressed for each food type as the relative importance in diet (\%). ${ }^{1}$ Each occurrence of a food type in a scat was calculated as $1,{ }^{2}$ biomass consumed was calculated as in Weaver (1993) suitable for identified mammal prey only, ${ }^{3}$ including an unknown fraction of calves of the year, since hair from adult and calf moose are indistinguishable, ${ }^{*}$ - trace amount $(<0.5 \%)$.

\begin{tabular}{|c|c|c|c|c|}
\hline \multirow{2}{*}{ Food type } & \multicolumn{2}{|c|}{ Summer (May-September) } & \multicolumn{2}{|c|}{ Winter (October-April) } \\
\hline & Occurrence $^{1}(\%)$ & $\operatorname{Biomass}^{2}(\%)$ & Occurrence $(\%)$ & Biomass $(\%)$ \\
\hline Adult moose & 33 & 74 & \multirow{2}{*}{$86^{3}$} & \multirow{2}{*}{$96^{3}$} \\
\hline Calf moose & 25 & 14 & & \\
\hline Badger & * & * & 1 & * \\
\hline Beaver & 2 & 1 & - & - \\
\hline Hare & 19 & 6 & 7 & 1 \\
\hline Small rodents & 2 & * & 1 & * \\
\hline Unidentified mammals & 3 & & 2 & \\
\hline Pig (carrion) & 4 & 2 & - & - \\
\hline Cattle (carrion) & 1 & 3 & 1 & 3 \\
\hline Dog & 1 & 1 & 1 & * \\
\hline Birds & 6 & & 1 & \\
\hline Fishes & * & & - & \\
\hline Invertebrates & 1 & & - & \\
\hline Berries & 3 & & 1 & \\
\hline
\end{tabular}


which was represented by 12 food types compared to 8 in winter (Table 1). Although identification was not positive, micro- and macroscopic examination of hairs from the category of unidentified mammals pointed to a medium-sized carnivore. Pig and cattle remains originated from baiting sites. The berries consisted mostly of blueberries Vaccinium myrtillus plus a small fraction of cowberries Vaccinium vitis-idaea.

Figure 1 shows the observed relative importance of different food categories recovered in the scat samples from Kurikka-pack (summer and winter) and Möhkö-pack (summer). The winter diet of the Kurikka-pack consisted almost entirely of moose, which accounted for $92 \%$ of all occurrences and $99 \%$ of consumed
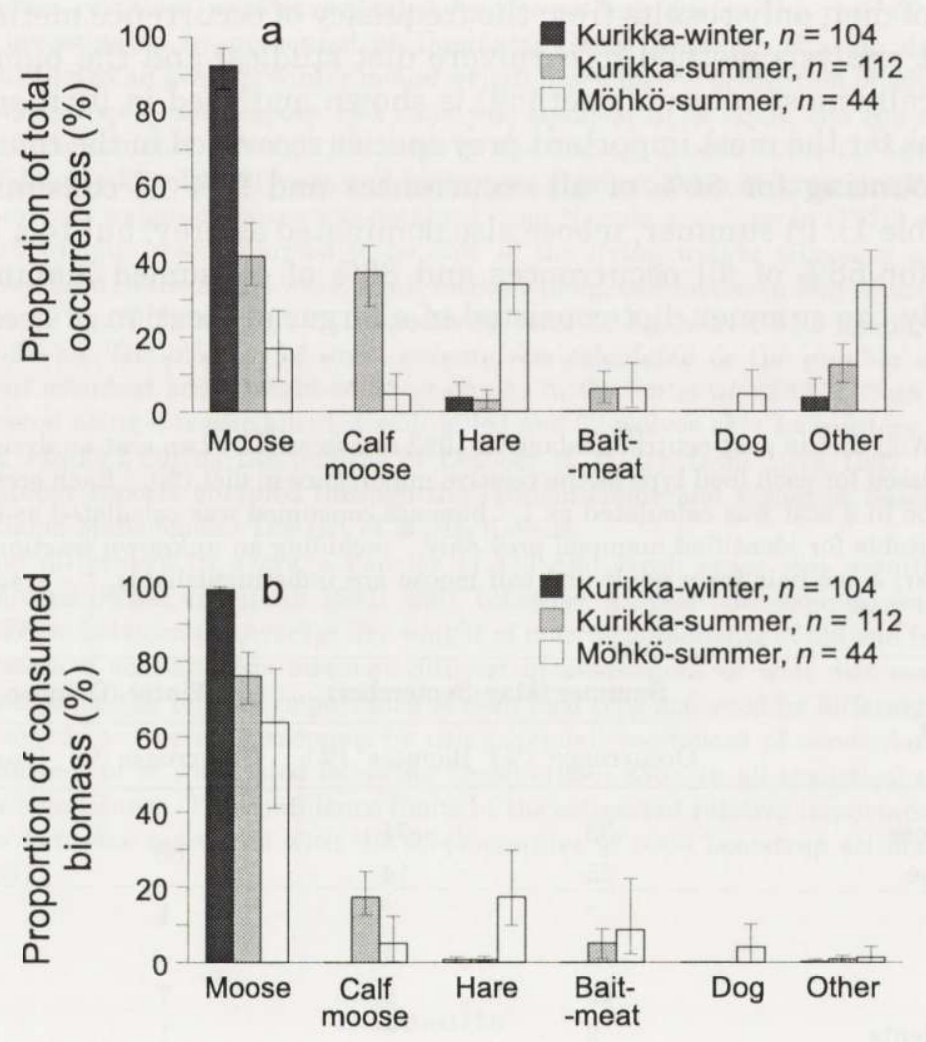

Fig. 1. Composition of the summer (1 May - 30 September) and winter diets (1 October - 30 April) of one pack of wolves (Kurikka-pack) and the summer diet of another pack (Möhkö-pack) based on analysis of scats collected in 1997 in east-central Finland. The wolf diet composition is expressed as the relative proportion of total occurrences of food types (a) and as the relative proportion of mammal biomass ingested using the linear regression model of Weaver (1993) (b). The bars indicate 95 -percentiles confidence intervals generated by bootstrap simulation (5000 repetitions). In the winter season the moose category includes adults and calves of the year in unknown proportions, since hairs from adult and calf moose are indistinguishable. Bait meat includes cattle and pigs. 
mammal biomass. Four other food types were identified from winter scats: hare, small rodents, badger and birds. In summer, moose also dominated as prey for the Kurikka-pack, accounting for $79 \%$ of all occurrences and $93 \%$ of consumed mammal biomass. The secondary food types in the summer diet consisted of 7 food types: hare, beaver, small rodents, bait-meat, birds, insects and berries. Each of these food types contributed between $2-4 \%$ to the diet by the frequency of occurrence method.

In Möhkö-pack moose accounted for $22 \%$ of all occurrences and $69 \%$ of consumed mammal biomass. Other food types represented in the scat sample from Möhkö-pack were (in order of importance according to the frequency of occurrence method): hare $(34 \%)$, unidentified mammals $(12 \%)$, berries $(8 \%)$, birds $(6 \%)$, bait meat (6\%), dog and small rodents (each 5\%), badger and fish (each 1.5\%).

Comparison of the diet of the two different packs revealed an inter-pack difference in summer diet (cf Fig. 1). The lower exploitation of moose by the Möhkö-pack was compensated by a greater use of secondary prey types. Especially the use of hare was pronounced, although still far less important than moose when converted to consumed biomass (17\%). The comparable percentage for hare in the Kurikka-pack is $1 \%$. Expressed in terms of relative numbers consumed (see Table 2) the Möhkö-pack approximately ate 18 hares for every moose, while the Kurikka-pack ate approximately 0.5 hare for every moose. Dog, badger, unidentified mammals and fish were only represented in the Möhkö diet, while beaver and insects only occurred in scats from the Kurikka-pack.

In the sample of wolf-killed moose found in the study area during winter time, adults (>1 year) made up 58\% $(n=21)$ and calves $(\leq 1$ year) $42 \%(n=15)$ and in one case age could not be determined. In the province of North-Karelia, Finland, the mean $(n=42)$ body weight of male wolves $( \pm \mathrm{SD})$ was $38 \pm 8 \mathrm{~kg}$ (range: $25-55 \mathrm{~kg}$ ) and the mean $(n=25)$ female wolf weighed $31 \pm 5 \mathrm{~kg}$ (range: $23-42 \mathrm{~kg}$ ).

Table 2. Relative numbers of adult moose, calf moose and hare consumed during summer by two packs of wolves in east-central Finland in 1997. ${ }^{a}$ As in Weaver (1993), ${ }^{b}$ for adult moose approx. $0.75 \times$ whole weight, for moose calf and hare approx. $0.90 \times$ whole weight (Peterson et al. 1984). Whole body weight, see text.

\begin{tabular}{|c|c|c|c|c|c|}
\hline \multirow{2}{*}{ Parameter } & \multirow{2}{*}{$\begin{array}{l}\text { Wolf } \\
\text { pack }\end{array}$} & \multirow{2}{*}{$\begin{array}{l}\text { Adult } \\
\text { moose }\end{array}$} & \multicolumn{2}{|c|}{ Calf moose } & \multirow{2}{*}{ Hare } \\
\hline & & & May-June & July-September & \\
\hline \multirow{2}{*}{$\begin{array}{l}\text { (A) Relative proportion } \\
\text { of biomass ingested }{ }^{\mathrm{a}}(\%)\end{array}$} & Kurikka & 76 & 7 & 10 & 1 \\
\hline & Möhkö & 64 & 3 & 2 & 17 \\
\hline (B) Consumable weight ${ }^{\mathrm{b}}(\mathrm{kg})$ & & 255 & 27 & 63 & 2.5 \\
\hline $\begin{array}{l}\text { (C) Numbers consumed } \\
\text { relative to adult moose }\end{array}$ & Kurikka & 1.0 & 0.9 & 0.5 & 1.3 \\
\hline$(\mathrm{A} / \mathrm{B})$ ! $\left(\mathrm{A}_{\text {adult moose }} / \mathrm{B}_{\text {adult moose }}\right)$ & Möhkö & 1.0 & 0.4 & 0.1 & 27.1 \\
\hline
\end{tabular}




\section{Discussion}

Scat composition was apparently altered due to weathering, since the average density was significantly lower for old scats than for fresh scats. Old scats contained on average a slightly larger proportion of macro-components by dry weight than fresh scats, although the difference was not statistically significant. The larger proportion of macro-components in the old scats is presumably caused by some of the microscopic fraction being washed out in the weathering process. Reynolds and Aebischer (1991) found the macroscopic fraction of fox scats to have a lower density than the microscopic fraction and assuming this also holds for wolf scats, loss of microscopic fraction can partly explain the lower density in old scats. Since the macroscopic fraction was fairly intact after weathering, the difference in density is believed not to significantly affect the results of this study.

Wolf diet studies conducted in Europe reveal that wolves Canis lupus often consume a wide spectrum of different prey species, but the major food source is wild ungulates (eg Okarma 1995, Olsson et al. 1997). In our study area the dependence of wolves on ungulates was also clearly demonstrated, as moose was found to constitute far the most important food source in both summer and winter. The forest ecosystem of east-central Finland differ ecologically from most other wolf habitats in Europe, as it only supports one wild ungulate species, the moose. Throughout Europe a richer community of $2-5$ species of ungulates is usually found, except in tundra regions of the far north, where reindeer is the only ungulate species (Okarma 1995). This difference in ungulate prey base prevents a direct comparison of the relative importance of moose in the diet between our study area and most European wolf habitats. An exception is part of the neighbouring north-western Russia, where moose also is the only or dominating wild ungulate. In the regions of Pskov, Leningrad and Karelia in Russia, moose remains appeared in $78-84 \%$ of collected scats (P. I. Danilov, unpubl.). The share of moose in the diet is similar to our findings of $72 \%$ (summer) and $90 \%$ (winter), when frequency data is calculated as a percentage of the total number of scats instead of the total number of occurrences. In Alaska and Canada, forest ecosystems with very similar species composition and weather regime as in east-central Finland (ie northern boreal forest, where moose is the only or dominant wild ungulate) are widespread (Gasaway et al. 1992). In such ecologically comparable study areas, the relative importance of moose ranges from 65-97\% of consumed mammal biomass in the summer diet (estimated on scat analysis; Fuller and Keith 1980, Peterson et al. 1984, Messier and Créte 1985, Ballard et al. 1987, Gasaway et al. 1992), which resembles the 69-93\% estimated in our Finnish study area.

In areas where wolves and man share the habitat, the diet of wolves can consist of a considerable amount of food of anthropogenic origin. Wolves may prey on livestock and scavenge on carrion available at baiting sites or garbage dumps (Salvador and Abad 1987, Leśniewicz and Perzanowski 1989, Meriggi et al. 1996). The consumption of man-related food sources by the opportunistic wolf have been 
suggested to be explained by factors such as scarcity of wild ungulates, abundant anthropogenic food sources, disruption of pack social structure size due to intensive hunting and husbandry practices (Bibikov 1982, Okarma 1995). The appearance of pig and cattle remains in the scat sample from east-central Finland implies scavenging behaviour of the wolves, since carcasses of these two species were available at baiting sites, while no pigs or cattle were reported killed in the area during the study period. Although no livestock was observed killed by wolves in our study area, each year several incidences of attacks by wolves on livestock (mostly sheep and reindeer) is reported elsewhere in Finland and compensation is paid for damages caused by large carnivores (Ministry of Agriculture and Forestry 1996). Dogs only accounted for a very small proportion of the overall wolf diet. Nevertheless, the killing of dogs by wolves is problematic, because of the emotional connection between humans and dogs and the economic value dogs represent (compensation paid by the Finnish government can amount 4500 US-dollars for a wolf-killed dog). Reports from the Game Management District of North Karelia $\left(21500 \mathrm{~km}^{2}\right.$ ) showed that during 1997, a minimum of 22 dogs were killed or injured by wolves. In Finland dogs are widely used in sport-hunting of moose and bears and a large share of wolf-killed dogs are killed during the autumn hunting season. Winter is another season with relatively many incidents of wolf-dog encounters. Dogs are often chained outside houses, and this tradition offers no protection against wolf attacks.

Traffic kills of moose were also used as bait for large carnivores, but since only a few moose $(n=3)$ were offered as bait and of which a considerable amount was observed eaten by wolverines, probably a negligible fraction of the scat sample contained scavenged moose originating from baiting sites. In scat-analysis it is not possible to distinguish between predation and scavenging, but other studies have revealed that scavenging by wolves on moose may constitute a considerable source of food for wolves. For example, Forbes and Theberge (1992) found that the majority $(83 \%)$ of examined carcasses $(n=30)$ were scavenged by wolves after dying of non-wolf related causes. Messier and Créte (1985) found that the degree of scavenging was related to moose density, the ratio of killed to scavenged moose increased from $6: 1$ to $1: 1$ from an area of high moose density $\left(0.37 \mathrm{moose} / \mathrm{km}^{2}\right)$ to an area of low moose density $\left(0.17 \mathrm{moose} / \mathrm{km}^{2}\right)$. To our knowledge, the dynamic of scavenging vs predation on wild ungulates by wolves largely remains to be investigated in Europe.

Comparison of the summer diet of the two wolf packs revealed that the Mökhö-pack consumed both more food types and a larger proportion of secondary food types than the Kurikka-pack. Several authors report a difference in diet between packs, which colonize neighbouring areas (eg Fuller and Keith 1980, Messier and Créte 1985). As summarized by Okarma (1995), diet specialization by individual wolf packs may be related to wolf pack size, pack-specific feeding habits, density and availability of alternative prey species, environmental conditions within territories (eg snow conditions) and hunting pressure on wolves. Unfor- 
tunately no estimates or indices of such features exist specifically for the two areas, so a comparative approach is not possible. An exception is the abundance of dogs, which can be indexed by the human population density and the reason why dogs are only represented in the summer diet of the Mökhö-pack may be related to the more dense human population in the area occupied by this pack.

Acknowledgements: Finnish Game and Fisheries Research Institute provided financial and logistic support for this study; we thank I. Kojola for his support and co-operation. We are very grateful to the staff at Ilomantsi Game Research Station for their helpfulness and co-operation; we thank T. Nygrén for providing useful moose data, K. Nygrén for hours of translation and logistical assistance. We sincerely thank the large number of local people for their assistance and support of the project; we especially thank P. Lyytikainen for indispensable field assistance. P. Ciucci provided good advise on laboratory techniques and the statistical assistance by P. Sunde is greatly appreciated.

\section{References}

Ballard W. B., Whitman J. S. and Gardner C. L. 1987. Ecology of an exploited wolf population in south-central Alaska. Wildlife Monographs 98: 1-54.

Bibikov D. I. 1982. Wolf ecology and management in the USSR. [In: Wolves of the World. Perspectives of behavior, ecology and conservation. F. H. Harrington and P. C. Paquet, eds]. Noyes Publications, New Jersey: 120-133.

Blood D. A., McGillis J. R. and Lovaas A. L. 1967. Weight and measurements of moose in Elk Island National Park, Alberta. The Canadian Field-Naturalist 81: 263-269.

Ciucci P., Boitani L., Pelliccioni E. R., Rocco M. and Guy I. 1996. A comparison of scat-analysis methods to assess the diet of the wolf (Canis lupus). Wildlife Biology 2: 37-48.

Debrot S., Fivaz G., Mermod C. and Weber J. M. 1982. Atlas des poils de mammifères d'Europe Institut de Zoologie, Université de Neuchâtel: 1-208.

Floyd T. J., Mech L. D. and Jordan P. A. 1978. Relating wolf scat content to prey consumed. The Journal of Wildlife Management 42: 528-532.

Forbes G. J. and Theberge J. B. 1992. Importance of scavenging on moose by wolves in Algonquin Park, Ontario. Alces 28: 235-241.

Fuller T. K. and Keith L. B. 1980. Wolf predation dynamics and prey relationships in northeastern Alberta. The Journal of Wildlife Management 44: 583-602.

Gasaway W. C., Boertje R. D., Grangaard D. V., Kelleyhouse D. G., Stephenson R. O. and Larsen D. G. 1992. The role of predation in limiting moose at low densities in Alaska and Yukon and implications for conservation. Wildlife Monographs 120: 1-59.

Helle P., Wikman M., Helle E., Belkin V., Bljudnik L. and Danilov P. 1997. [Game winter censuses by triangular transects in Finland and linear transects in Karelian Republik 1997]. Riistantutkimuksen tiedote 147: 1-25. [In Finnish]

Kalliola R. 1973. [Finnish geography of plants]. WSOY, Porvoo: 1-308. [In Finnish]

Leśniewicz K. and Perzanowski K. 1989. The winter diet of wolves in Bieszczady Mountains. Acta Theriologica 34: 373-380.

Meriggi A., Brangi A., Matteucci C. and Sacchi O. 1996. The feeding habits of wolves in relation to large prey availability in northern Italy. Ecography 19: 287-295.

Messier F. and Créte M. 1985. Moose-wolf dynamics and the natural regulation of moose populations. Oecologia 65: 503-512.

Ministry of Agriculture and Forestry 1996. Management of bear, wolf, wolverine and lynx in Finland. Report of the Working Group for Large Terrestrial Carnivores 6a: 1- 43.

Nygrén K. 1980. Effect of the wolf on the moose population. Soumen Riista 28: 71-78. [In Finnish with English summary] 
Nygrén T. and Nygrén K. 1976. [Moose and moose hunting in Finland]. Riistantutkimusosaston tiedonantoja 2(4): 2-33. [In Finnish]

Nygrén T. and Pesonen M. 1989. Bag size and meat production of moose hunting in Finland 1964-87. Suomen Riista 35: 128-153. [In Finnish with English summary]

Okarma H. 1995. The trophic ecology of wolves and their predatory role in ungulate communities of forest ecosystems in Europe. Acta Theriologica 40: 335-386.

Olsson O., Wirtberg J., Andersson M. and Wirtberg I. 1997. Wolf (Canis lupus) predation on moose (Alces alces) and roe deer (Capreolus capreolus) in south-central Scandinavia. Wildlife Biology 3 : $13-25$.

Peterson R. L. 1955. North American moose. University of Toronto Press, Toronto: 1-280.

Peterson R. O., Woolington, J. D. and Bailey T. N. 1984. Wolves of the Kenai Peninsula, Alaska. Wildlife Monographs 88: 1-52.

Pulliainen E. 1965. Studies on the wolf (Canis lupus) in Finland. Annales Zoologici Fennici 2: 215-259.

Pulliainen E. 1979. Ecology of the wolf in the settled areas of Finland. [In: The behavior and ecology of wolves. E. Klinghammer, ed]. Proceedings of the Symposium on the Behavior and Ecology of Wolves held on 23-24 May 1975 at the Annual Meeting of the Animal Behavior Society in Wilmington, Garland Publishing Inc, New York: 84-92.

Pulliainen E. 1982. Behavior and structure of an expanding wolf population in Karelia, Northern Europa. [In: Wolves of the World. Perspectives of behavior, ecology and conservation. F. H. Harrington and P. C. Paquet, eds]. Noyes Publications, New Jersey: 134-145.

Pulliainen E. 1993. The wolf in Finland. [In: Wolves in Europe: Status and perspectives. C. Promberger and W. Schröder, eds]. Proceedings of the Wolves in Europe Workshop, Oberammergau, Germany, April 2nd, 1992. Münich Wildlife Society, Ettal: 14-20.

Reynolds J. C. and Aebischer N. J. 1991. Comparison and quantification of carnivore diet by faecal analysis: a critique, with recommendations based on a study of the fox (Vulpes vulpes). Mammal Review 21: 97-122.

Salvador A. and Abad P. L. 1987. Food habits of a wolf population (Canis lupus) in León province, Spain. Mammalia 51: 45-52.

Siegel S. 1956. Nonparametric statistics for the behavioral science. McGraw-Hill Kogakusha, Ltd., Tokyo: 1-312.

Sokal R. R. and Rohlf F. J. 1981. Biometry. W. H. Freeman and Company, San Francisco: 1-856.

Teerink B. J. 1991. Hair of West-European mammals. Cambridge University Press, Great Britain: $1-224$.

Weaver J. L. 1993. Refining the equation for interpreting prey occurrence in gray wolf scats. The Journal of Wildlife Management 57: 534-538.

Weaver J. L. and Fritts S. H. 1979. Comparison of coyote and wolf scat diameters. The Journal of Wildlife Management 43: 786-788.

Received 14 May 1999, accepted 6 March 2000. 